\title{
Platinum Group Elements (PGE) distribution and mobility during post magmatic processes in ophiolite chromitites
}

M. BUSSOLESI ${ }^{1 *}$, G. GRIECO ${ }^{1}$, F. ZACCARINI $^{2}$, E. TZAMOS $^{3}$, A. ESLAMI ${ }^{4}$

${ }^{1}$ Department of Earth Sciences, University of Milan, 20133

Milan, Italy (*correspondence micol.bussolesi@unimi.it)

${ }^{2}$ University of Leoben, A-8700 Leoben, Austria

${ }^{3}$ Department of Chemistry, Aristotle University of Thessaloniki, 54124, Thessaloniki, Greece

${ }^{4}$ Department of Earth Sciences, University of Grenoble,

Grenoble, France

PGE in ophiolite chromitites are hosted mainly in Platinum Group Minerals (PGM). Ophiolite chromitites are usually enriched in IPGE (Os, Ir, Ru) with respect to PPGE (Pt, Pd, Rh), and have average PGE total contents of 300-400 ppb. In order to assess the role of serpentinization and chloritization in the re-mobilization of PGE, four case studies are presented: serpentinized chromitites from AbdashtSoghan (Iran) and Skyros (Greece) and chloritized chromitites from the of Gomati and Nea Roda (Greece).

Chromitites in all the localitites have highly variable PGE contents, from few ppb (Nea Roda and Skyros) to hundreds (Abdasht-Soghan) or thousands of ppb (Gomati).

The PGM assemblage is highly variable in the different localitites. In chloritized samples of Gomati and Nea Roda, all PGM are primary sulfides and sulfarsenides, namely laurite, irarsite and unknown Ir-Ni-Fe-Cu sulfides, found as inclusions in unaltered chromite and presenting euhedral shape. In serpentinized samples of Abdasht-Soghan and Skyros the PGM assemblage is more variable. Primary PGM are mainly euhedral laurites enclosed in unaltered chromite, while secondary PGM are low-S sulfides or alloys associated to fractured or altered zones and presenting subhedral to anhedral shapes.

Differences in the mineralogical assemblage in serpentinized and chloritized samples can be attributed to a variability in $\mathrm{fS}_{2}$ conditions during post-magmatic processes.

During serpentinization PGE sulfides where partially transformed into PGE alloys, with complete removal of S and partial removal of PGE, following the order $\mathrm{Ru}>\mathrm{Rh}>\mathrm{Os}$. The PGE remobilization affected PGE normalized patterns that show a peculiar Os peak. Widespread chloritization at Gomati and Nea Roda did not affect PGM assemblage and PGE contents reflect primary distribution with the highest contents, at $3000 \mathrm{ppb}$ for supra-moho chromitites. 